\title{
Thrombotic obstruction of the central venous catheter in patients undergoing hematopoietic stem cell transplantation ${ }^{1}$
}

\author{
Kátia Michelli Bertoldi Arone ${ }^{2}$ \\ Cleyton Zanardo de Oliveira ${ }^{3}$ \\ Lívia Maria Garbin ${ }^{4}$ \\ Paula Elaine Diniz dos Reis ${ }^{5}$ \\ Cristina Maria Galvão ${ }^{6}$ \\ Renata Cristina de Campos Pereira Silveira ${ }^{7}$
}

This is an integrative literature review with the aim of summarizing the prevention measures and treatment of thrombotic obstruction of long-term semi-implanted central venous catheters, in patients undergoing hematopoietic stem cell transplantation. The sample consisted of seven studies, being two randomized controlled clinical trials, three cohort studies and two case series. Regarding the prevention measures, one single study demonstrated effectiveness, which was a cohort study on the oral use of warfarin. In relation to the treatment measures, three studies evidenced effectiveness, one highlighted the efficacy of streptokinase or urokinase, one demonstrated the benefit of using lowmolecular-weight heparin and the other treated the obstruction with heparin or urokinase. Catheter patency research shows a restricted evolution that does not follow the evolution of transplantations, mainly regarding nursing care.

Descriptors: Central Venous Catheterization; Hematopoietic Stem Cell Transplantation; Bone Marrow Transplantation; Thrombosis.

\footnotetext{
${ }^{1}$ Paper extracted from Master's Thesis "Obstrução trombática do cateter venoso central no transplante de células-tronco hematopoéticas", presented to Escola de Enfermagem de Ribeirão Preto, Universidade de São Paulo, WHO Collaborating Centre for Nursing Research Development, Brazil.

${ }^{2}$ RN, Instituto de Ensino e Pesquisa, Hospital de Câncer de Barretos, Brazil.

${ }^{3}$ MSc, Instituto de Ensino e Pesquisa, Hospital de Câncer de Barretos, Brazil.

${ }^{4}$ MSc, Escola de Enfermagem de Ribeirão Preto, Universidade de São Paulo, WHO Collaborating Centre for Nursing Research Development, Brazil.

${ }^{5}$ PhD, Adjunct Professor, Faculdade de Ciências da Saúde, Universidade de Brasília, Brazil.

${ }^{6}$ PhD, Full Professor, Escola de Enfermagem de Ribeirão Preto, Universidade de São Paulo, WHO Collaborating Centre for Nursing Research Development Brazil.

${ }^{7}$ PhD, Professor, Escola de Enfermagem de Ribeirão Preto, Universidade de São Paulo, WHO Collaborating Centre for Nursing Research Development, Brazil.
} 


\title{
Obstrução trombótica do cateter venoso central em pacientes submetidos ao transplante de células-tronco hematopoéticas
}

Trata-se de revisão integrativa da literatura, cujo objetivo foi sintetizar as medidas de prevenção e tratamento da obstrução trombótica no cateter venoso central de longa permanência e semi-implantado, em pacientes submetidos ao transplante de célulastronco hematopoéticas. A amostra foi constituída por sete estudos, sendo dois ensaios clínicos controlados randomizados, três estudos de coorte e duas séries de casos. Quanto às medidas de prevenção, um único estudo que se mostrou efetivo abordando pesquisa de coorte sobre o uso da varfarina oral. Em relação às medidas de tratamento, três estudos evidenciaram efetividade: um apontou a eficácia da estreptoquinase ou uroquinase, outro estudo mostrou benefício no uso de heparina de baixo peso molecular e outro tratou a obstrução com heparina ou uroquinase. Nota-se que a evolução da pesquisa referente à perviedade do cateter foi restrita, não acompanhando a evolução do transplante, principalmente no que tange aos cuidados de enfermagem.

Descritores: Cateterismo Venoso Central; Transplante de Células-Tronco Hematopoéticas; Transplante de Medula Óssea; Trombose.

\section{Obstrucción trombótica del catéter venoso central en pacientes sometidos al trasplante de células-tronco hematopoyéticas}

\begin{abstract}
Se trata de una revisión integradora de la literatura con objeto de sintetizar las medidas de prevención y tratamiento de obstrucción trombótica del catéter venosos central de larga permanencia y semi-implantado, en pacientes sometidos al trasplante de células $\square$ tronco hematopoyéticas. La muestra abarcó a siete estudios: dos ensayos clínicos controlados aleatorizados, tres estudios de cohorte y dos series de casos. Respecto a las medidas de prevención, fue identificado un único estudio efectivo, uno cohorte sobre el uso de la warfarina oral. Sobre las medidas de tratamiento, tres estudios evidenciaron efectividad, uno apuntó la eficacia de la estreptoquinasa o uroquinasa, otro mostró beneficio del uso de heparina de bajo peso molecular y otro trató la obstrucción con heparina o uroquinasa. Se observa que la evolución de la investigación sobre la permeabilidad del catéter fue limitada, no acompañando la evolución del trasplante, principalmente respecto a los cuidados de enfermería.
\end{abstract}

Descriptores: Cateterismo Venoso Central; Trasplante de Células Madre Hematopoyéticas; Trasplante de Medula Ósea; Trombosis.

\section{Introduction}

Hematopoietic stem cell transplantation (HSCT) is a relatively new procedure used to treat diseases once thought to be incurable, which has significantly changed the prognosis of patients with these diseases ${ }^{(1)}$. Upon admission to the transplantation unit, each patient is subjected to the implantation of a long-term, tunneled, semi-implanted central venous catheter (CVC), for the initiation of conditioning, with the Hickman catheter still the most commonly used(2). Usually, maintaining the patency of the CVC is performed by the introduction of isotonic saline solution with heparin in a concentration ranging from $10 \mathrm{UI} / \mathrm{ml}$ to $100 \mathrm{UI} / \mathrm{ml}$. The most frequent adverse reactions related to the use of heparin are bleeding, anemia and thrombocytopenia. Clinically manifested thrombosis related to the CVC occurs in $03 \%$ to $38.3 \%$ of adult patients, suggesting a frequency from 0.02 to 0.92 events per 1000 catheter days( ${ }^{(3)}$. However, when considering objectively diagnosed thrombosis, 
this complication occurs in between $27 \%$ and $66 \%$ of patients $^{(4)}$.

Infection of the intravascular catheter related to the presence of fibrin or intraluminal thrombosis is more likely because these substances act as a matrix for bacterial adhesion, promoting colonization of the catheter ${ }^{(5)}$. Catheter-related thrombosis and infection are the most important complications in cancer patients that require venous access over a long period(6). Given the above, the nursing team should adopt effective measures to prevent thrombotic obstruction of the catheter. The maintenance of the CVC is crucial to the success of the HSCT and, given that the nursing team handles the CVC intensely, it is extremely important that these professionals comprehend the actions that ensure its permanence in situ without causing complications for the patient, such as its early removal. From this, interest has emerged in the area related to the measures that are effective in maintaining the intraluminal patency of the CVC in patients undergoing HSCT. The aim of this study is to summarize the measures related to the prevention and treatment of thrombotic obstructions of the longterm, semi-implanted CVC in patients undergoing HSCT.

\section{Method}

It is an integrative review (IR), developed according to the following steps: elaboration of the research question, search for primary studies, data extraction, evaluation of primary studies, analysis and synthesis of the results of the review and presentation of the review $^{(7)}$. The development of the research question was based on the PICO strategy, in which the P is attributed to - patients undergoing HSCT with the use of long-term and semi-deployed CVCs, the I to - preventive care and treatment of the thrombotic obstruction of the longterm, semi-deployed CVC, the C to - saline solution flush with heparin, and the $O$ to - prevention of thrombotic obstruction of the long-term semi-deployed CVC. Thus, the question prepared to conduct the IR was: "What are the measures for the prevention and treatment of thrombotic obstruction related to long-term semiimplanted central venous catheter in HSCT patients?"

The search for the primary studies was conducted in the Lilacs, Cinahl, Medline, Embase and Cochrane Library electronic databases, as was the checking of the references cited in the primary studies selected. The controlled descriptors used in the search were bone marrow transplantation or hematopoietic stem cell transplantation; catheter delay or central venous catheterization; venous thromboembolism; complications. Furthermore, to ensure a wide search the following keywords were used, which were identified in the studies that address the topic of interest: central venous catheters or central venous access device or central venous line or Hickman catheter; occlusion or obstruction; catheter-related thrombosis. The controlled descriptors and keywords were used in Portuguese or English, depending on the database. The inclusion criteria were as follows: articles that addressed the prevention and treatment of thrombotic obstruction of long-term, semi-implanted CVCs in HSCT patients, published in English, Spanish or Portuguese during the last 30 years. The exclusion criteria were: articles that included different populations of patients with longterm, semi-implanted CVCs, as well as articles on the preclinical phase.

The search and selection of the primary studies were conducted in September 2010. A total of 312 primary studies were identified, of which 55 were preselected by reading their titles and abstracts, with 28 from Medline, 25 from Embase and of two from Cinahl. Of the 55 pre-selected studies, 48 were excluded for the following reasons: 31 were duplicates in the database and between the databases, eight studied the general cancer population, six were unrelated to the theme and three studies did not meet the language criteria established in the selection. The IR sample consisted of seven primary studies. In order to systematize the extraction of the data from the articles included in this review a validated instrument ${ }^{(8)}$ was used, after approval by the authors. The data extraction was performed independently by two reviewers, with no divergences between them. The final analysis of the results of each primary study was conducted with the assistance of a statistician. The primary studies were classified according to the evidence level, in order to present the strength of the evidence of each ${ }^{(9)}$. To evaluation the methodological quality of the randomized controlled trials (RCTs), Jadad scoring ${ }^{(10)}$ was applied.

\section{Results}

As mentioned, the IR sample was composed of seven primary studies, with three $(43 \%)$ published in the 1990s and four (57\%) between 2000 and 2006. Regarding the journals and their impact factor in the Journal Citation Reports (JCR), two studies (28\%) were published in the journal Cancer, with an impact factor of 5.418 , one (14\%) in the journal Bone Marrow 
Transplantation, impact factor 2.998, one (14\%) in the American Journal of Hematology, impact factor 2.61, one $(14 \%)$ in the journal Pharmacotherapy, impact factor 2.726 , one $(14 \%)$ in the European Journal of Cancer, impact factor 4.121 and one (14\%) in the Journal of Parenteral and Enteral Nutrition, with an impact factor of 2.231 .

The primary studies were grouped into two themes, namely: measures for the prevention of thrombotic obstruction (five studies) ${ }^{(5,11-14)}$ and measures for the treatment of thrombotic obstruction (three studies) (14-16). One study ${ }^{(14)}$ was included in the two thematic categories because it addressed both the prevention and treatment of thrombotic obstruction. In relation to the study designs and their evidence levels, two RCTs were identified which were classified at evidence level II, three cohort studies of evidence level IV and two cases series of evidence level VI. The two RCTs presented a Jadad score of $02^{(5)}$ and $03^{(13)}$, respectively.

The first primary study included in the $\mathrm{IR}^{(11)}$ had a sample of 382 patients who underwent HSCT, which were divided into three groups. The occurrence of CVC-related thrombosis was evaluated, with swelling, redness of the limb and/or venous engorgement being regarded as signs and symptoms of thrombosis. In the case of the occurrence of the signs and symptoms, the thrombosis was confirmed using Doppler ultrasound. The first cohort comprised 161 patients and 163 catheters, and the patients did not receive prophylaxis. In the second cohort 123 patients and 25 catheters were evaluated, with these patients receiving 2,850UI/ day subcutaneous nadroparin as prophylaxis, after the insertion of the catheter, for a duration of six days. The third cohort was formed by 98 patients and 102 catheters, with prophylaxis of 5,700UI/day of subcutaneous nadroparin for a period of 10 days after catheter insertion. Among the patients evaluated, 27 developed signs and symptoms of thrombosis, 10 from the first cohort, 10 from the second and seven from the third. The occurrence of thrombosis related to the catheter was $6.9 \%$ and had a mean time of occurrence of 22 days after insertion of the CVC (05 to 92 days). The incidence of thrombosis was similar in all three groups $(p=0.58)$, being higher in the double or triple lumen catheters compared to the single lumen catheters (9.6 and $3.7 \%$ respectively). In this study, nadroparin was not recommended as prophylaxis for CVC-related thrombosis. One possible explanation for these results is the short period of administration of nadroparin, with the continuation of this medication for a longer period possibly leading to greater effectiveness, although, increasing the risk of bleeding. The data suggest that the thrombosis was initiated by the insertion of the catheter, therefore the use of insertion techniques that result in less trauma to the vessel wall might reduce the risk of catheter-related thrombosis ${ }^{(11)}$.

One of the RCTs(5) evaluated compared the occurrence of thrombosis in patients who took part in the control group $(n=48)$ and received heparin (50UI in $5 \mathrm{ml}$ of saline solution) with those who took part in the experimental group $(n=52)$ and received urokinase $(5,000 \mathrm{UI}$ in $2 \mathrm{ml}$ of saline solution). In both groups the injection of the solution was started 48 hours after the insertion of the catheter and was carried out twice a week. Signs and symptoms of thrombosis related to the Hickman catheter were evaluated, which was defined by clinical evidence of the presence of thrombi in the region of the catheter and confirmed by ultrasound. Among the patients that presented Hickman catheterrelated thrombosis, six belonged to the control group and eight to the experimental group. The twice weekly injection of urokinase, compared to heparin did not reduce complications such as obstruction and intraluminal thrombosis related to the CVC, thus, the use of urokinase was not recommended for the prevention of complications related to the CVC. However, in the analysis of the underlying condition for which transplantation was indicated, it was found that those patients who were affected by solid tumors presented a higher incidence of thrombotic complications when compared with the onco-hematological conditions(5).

One prospective cohort study(12) examined the safety and clinical efficacy of the use of oral warfarin. The study was performed with 228 patients, 175 with the Nutricath-S catheter (Vygon ${ }^{\circledR}$ ) and 53 with the Groshong catheter (Bard Access System ${ }^{\circledR}$ ). All the patients received prophylaxis with oral warfarin ( $1 \mathrm{mg} /$ day) started on the day of catheter insertion and interrupted when the platelet count went below 50,000/dl. In the presence of signs or symptoms related to thrombosis, such as edema, redness and/or venous engorgement, Doppler ultrasound was performed to confirm the venous thromboembolism. Four episodes of thrombosis were observed, with three related to the CVC. Of these events, two were thrombosis of the subclavian vein and one was a thrombosis of the subclavian vein with extension to the superior vena cava. The other event, considered unrelated, was thrombosis of the saphenous vein. Four of the followed patients developed bleeding, all with normal International Normalized Ratios. 
Statistical tests were used to evaluate the impact of the variables age, underlying disease, therapeutic regimen, number of previous chemotherapies performed and type of catheter used, however, no association was found between the variables investigated and the occurrence of the thrombotic event. It was concluded that the use of oral warfarin is safe and effective for use in hematologic patients who have undergone $\mathrm{HSCT}^{(12)}$.

In one, double-blinded, prospective $\mathrm{RCT}^{(13)}$ the hypothesis was tested that Lepirudin presents a superior effect to that of heparin in preventing the aggregation of fibrin in the catheter tip. Another hypothesis investigated was that effective anticoagulation would only be necessary for a few weeks to prevent the formation or long term accumulation of thrombi. This hypothesis was based on the fact that Lepirudin is adsorbed to the hydrophobic surface of the catheter, possibly leading to the maintenance of some anticoagulant activity. The sample included 49 adult patients undergoing allogeneic or autologous HSCT divided into two groups. The control group consisted of 24 patients and received a flush of $3 \mathrm{ml}$ of heparin, $100 \mathrm{UI} / \mathrm{ml}$ (300UI), in each lumen of the catheter, according to the protocol of the institution. The experimental group included 25 patients who received a $3 \mathrm{ml}$ flush of Lepirudin $100 \mu \mathrm{g} / \mathrm{ml}(300 \mu \mathrm{g})$ in each lumen of the catheter. After three to four weeks all the patients began receiving the heparin flush only. The efficacy of the interventions was measured by the frequency with which the introduction of alteplase was necessary for the treatment of catheter occlusion in the first 120 days after insertion. Five (20\%) patients in the experimental group and three $(13 \%)$ in the control group presented intraluminal obstruction and required treatment with alteplase, which resolved seven of the eight obstructions. All the obstructions occurred in the first 60 days. The use of Lepirudin was not shown to be more effective than heparin in preventing intraluminal obstruction $(p=0.62)$, which, according to the authors, may be related to the conservative dose of Lepirudin used. However, it was noted that the use of higher doses would be problematic since the excretion of the drug is renal and any degree of renal failure could increase the level of anticoagulation ${ }^{(13)}$.

One case series ${ }^{(14)}$ included five patients undergoing autologous HSCT, with semi-implanted CVCs, who presented catheter-related thrombosis. In these patients the prevention of thrombosis and obstruction of the CVC was performed with an occasional flush of $5,000 \mathrm{UI} / \mathrm{ml}$ of heparin. After the confirmation of the catheter-related thrombosis, where possible the device was removed and the patients received $40 \mathrm{mg}$ of subcutaneous enoxaparin twice daily (treatment 1 ) or an intravenous bolus of 5,000UI of unfractionated heparin and a further 24,000UI in 24 hours (treatment 2). From four to 10 days after the initiation of the therapy the heparin was replaced by $40 \mathrm{mg}$ of enoxaparin twice daily. All the patients received enoxaparin for a period of 14 days. Before starting the treatment, the patients with signs and symptoms of thrombosis underwent contrast venography or ultrasonography to confirm the presence of the thrombus and were re-evaluated after the treatment using the same diagnostic method. In all cases, the catheters were removed, since an alternative route of venous access was identified in all patients. Three patients received treatment 1 and two patients initially received treatment 2 . The signs and symptoms of thrombosis disappeared from one to four days after the beginning of both therapies. The imaging examinations were repeated and demonstrated the absence of thrombi in three patients and the presence of residual thrombi in two. It is reported that despite the small number of patients evaluated, enoxaparin is an effective and safe method to overcome the problems caused by catheter-related thrombosis and it is recommended that these data are confirmed by the performance of an RCT. The authors also emphasize that low-molecularweight heparin results in less hemorrhagic episodes than unfractionated heparin because it has no effect on the platelets, and that it presents a longer half-life and higher bioavailability after subcutaneous injection when compared to unfractionated heparin.

Another study(15) aimed to identify the factors related to thrombotic complications in the subclavian vein due to the insertion of a Hickman catheter and to evaluate their treatment measures. The sample consisted of 168 patients undergoing HSCT and 49 undergoing high dose chemotherapy treatment. When the thrombus was confirmed by contrast venography the patients received fibrinolytic therapy with streptokinase $(5,000$ to $25,000 \mathrm{UI} /$ hour $)$ or urokinase $(20,000$ to $200,000 \mathrm{UI} /$ hour). After the implementation of the intervention a complete response was considered when the thrombus was no longer observed; a partial response, when there was the presence of residual thrombus; and no response when the presence of the thrombus prevented the infusion of the contrast through the catheter. Thrombosis occurred in 23 patients (including eight patients who had had the catheter inserted at another institution). Of these, 19 thrombotic events occurred in the transplant patients, with the difference being significant $(p=0.03)$. 
Statistical analysis showed a higher rate of thrombosis free catheters in patients with platelet counts lower than $150,000 / d l$. Other factors that may be related to the occurrence of thrombosis are the intensity of the chemotherapy and the coexistence of two implanted catheters, since the length of thrombosis-free time was higher in the group of patients who had only one catheter implanted. Ten of 23 patients that presented catheter-related thrombosis received thrombolytic therapy with urokinase or streptokinase. Of these ten, seven cases presented a complete response. The authors recommend that thrombolytic therapy is used for restoration of the catheter function only when it is impossible to remove it, with removal the first alternative in cases of thrombosis(15).

The final study included in the IR, developed in the $1990 \mathrm{~s}^{(16)}$, evaluated the complications related to difficulty of blood aspiration through any lumen of the catheter, difficulty in intraluminal fluid infusion, accidental displacement, damage to the catheter that required repair or another intervention, and catheter removal for any reason other than discharge or death. The sample consisted of 111 patients undergoing HSCT with 143 catheters. The maintenance of the catheters was performed using heparin infusion. Clearance was performed by injecting $3 \mathrm{ml}$ of heparin at a dose of 1,000 U maintained for between 15 minutes and 24 hours or $2 \mathrm{ml}$ of urokinase $(5,000 \mathrm{UI} / \mathrm{ml})$ maintained for 15 to 30 minutes. Following this the reflux of blood from the catheter lumens was tested and, in the case of this not being successful, the treatment was repeated up to three times in four hours in patients with a platelet count higher than 20,000 and once every four hours in patients with a platelet count lower than 20,000. There were 55 episodes of no reflux in 37 catheters. Intervention was required in 35 of the episodes. In ten of the episodes the treatment of choice was the removal of the catheter. Among the other 25, six were treated with heparin, 16 with urokinase, two received treatment with both medications and in one case a surgical revision of the catheter route was performed. The authors concluded that adequate training regarding the management and maintenance of the CVC is essential for the early detection and intervention regarding abnormalities related to its operation. Many of the catheter-related complications are reversible, therefore interventions should be tried as alternatives prior to the removal of the device. The study recommends that clearance of catheters affected by thrombotic obstruction is performed with heparin or urokinase(16).

\section{Discussion}

The tested interventions differed between the studies regarding the types of drugs, dosage and route of administration. However, the use of heparin was seen to be predominant for the prevention and treatment of thrombotic obstruction in the long-term catheter. This can be attributed to the pharmacological characteristics and the low economic cost compared to the other possibilities. The catheter management in patients undergoing HSCT who develop catheter-related thrombosis is not yet standardized. The treatment strategies reported in the literature consist of thrombolytic therapy, systemic anticoagulation, removal of the catheter or a combination of two or more therapeutic modalities. In patients with non-hematologic diseases, who are not undergoing HSCT and that develop catheter-related thrombosis, the treatment of choice is the combination of low-molecularweight heparin, followed by administration of an oral anticoagulant for three to six months ${ }^{(17)}$.

The occurrence of venous thromboembolism in patients with hematological neoplasms has been shown to be similar to that observed in patients with solid tumors. These patients are known to be at higher risk for thrombosis ${ }^{(18)}$. One factor that seems to predispose to thrombosis is leukocytosis(19), which is common in HSCT patients with onco-hematological diseases. One of the commonly used medications in the HSCT units intended to prevent intraluminal thrombosis is heparin. However, this product may induce thrombocytopenia from five to 10 days after the initiation of treatment ${ }^{(20)}$. Heparin-induced thrombocytopenia (HIT) can be triggered even when used in small quantities ${ }^{(21)}$. Another problem is that errors in the dose can cause increased risk of bleeding(22). However, heparin is more costeffective when compared with other medications used in the prevention of thrombotic obstruction, such as urokinase $^{(5)}$.

A double blind RCT, showed that alteplase, when compared with urokinase, is more effective to perform thrombotic clearance of the catheter, 120 minutes after the medication infusion(23). Alteplase stimulates the conversion of plasminogen to plasmin, resulting in local fibrinolysis ${ }^{(24)}$. The efficacy of alteplase in catheter clearance is reported in the literature as being from 87 to $90 \%(25)$. After confirmation of the partial or total thrombotic obstruction of the CVC the infusion of the fibrinolytic agent alteplase is recommended, in a dilution of $2 \mathrm{mg}$ in $2 \mathrm{ml}$ of saline solution, in each catheter lumen, to wait for 30 minutes and, if necessary, to repeat 
the dosage after a period of six to eight hours ${ }^{(26)}$. Recombinant urokinase has been studied as a medication with potential for the management of obstructed CVCs in adults. This medication seems to have better efficacy when compared to alteplase, in the first 30 minutes, with a mean catheter clearance of $60 \%$ in patients. However, when taking into consideration the longer intraluminal time interval, recombinant urokinase is seen to be less effective than alteplase ${ }^{(27)}$.

In one prospective cohort study, 74 cancer patients were evaluated regarding the safety and effectiveness of the treatment strategy for catheter-related thrombosis. To this end, dalteparin (low-molecular-weight heparin) was used, followed by the use of oral warfarin for three months, without removal of the catheter. According to the authors no further episodes of thromboembolism occurred and the catheters were not removed(28).

One RCT involving 225 cancer patients using CVC, with the majority affected by hematological diseases, showed no difference in the occurrence of symptomatic thrombosis between the group receiving $1 \mathrm{mg}$ of warfarin and the placebo group. A limitation of this study was the unexpectedly low incidence of thrombosis, only 11 symptomatic catheter-related thromboses ${ }^{(29)}$. However, the treatment of thrombotic obstruction of the catheter is preferable to its removal, because this limits the interruption of the therapy, reduces patient trauma and reduces costs. The estimated cost for the reinsertion of a new intravascular device is US\$850-1500, depending on the type of catheter, which often exceeds the cost of the thrombolytic therapy to restore the patency of the catheter ${ }^{(30)}$.

In addition to the measures related to the prevention and treatment of the thrombotic obstruction of the CVC, it was sought to identify, in the studies analyzed, the care that could be adopted by the nursing staff to maintain the patency of the CVC, with only the importance of training the nursing team mentioned. This may have occurred because the majority of the studies evaluated were authored by physicians. The use of the catheter flush is common to maintain the patency of the device, but there are no studies in the literature that evaluate this intervention ${ }^{(4)}$. The flush is considered the first action to prevent fibrin formation and accumulation of drug residuals in the catheter lumen(31). However, it is important to preserve the integrity of the catheter during the flush procedure and for this it is necessary to understand the relationship between the size of the syringe and the force applied to the plunger. In some cases the obstruction of the CVC is directly attributable to an inadequate infusion technique, especially as regards the absence or failure of a suitable flush in the lumens of the device. Furthermore, an improper disconnection procedure of the catheter device without prior clamping of the manipulated lumen can create the same effect(32).

One systematic review identified 17 primary studies and five clinical guidelines on the use of the heparin flush, pressure caps and other interventions to maintain the patency of the CVC. The studies included evaluated patients who had semi-implanted CVCs, independent of the pathology and age. The results showed that the evidence for the use of the heparin flush, pressure caps, and other interventions, such as the urokinase flush to reduce CVC-related thrombotic obstruction, is derived from primary studies of low quality. Thus, the authors state that the available evidence is insufficient to support the clinical practice related to the maintenance of the catheter patency(22).

\section{Conclusions}

Among the studies that addressed prevention measures, only the cohort study in which oral warfarin was used from the day of CVC insertion indicated effective results in the prevention of obstruction. The other studies showed no statistically significant difference between the standard treatment and intervention tested. Regarding the treatment measures, three studies demonstrated effectiveness. One pointed out the efficacy of streptokinase or urokinase use, one demonstrated benefits in the use of low-molecularweight heparin and the other successfully treated the obstruction with heparin and urokinase. It was noted that the evolution of the studies on the patency of the CVC was restricted, not accompanying the evolution of the HSCT therapy, especially regarding nursing care, as they all deal with medication interventions, without addressing the non-medication aspects.

Despite an extensive search, the sample obtained was limited. However, the performance of this study was considered important since it enabled the mapping of the publications related to the topic of interest and the recognition of gaps, allowing new studies to be proposed that cover the specificities of the clientele studied. Additionally, the present study emphasizes the low number of studies conducted by nurses, considering that the handling and manipulation of the intravascular device, as well as the maintenance of the patency of the catheter, are priority responsibilities of these professionals. The results evidenced indicate the need 
to conduct studies to test nursing interventions in the prevention of catheter-related thrombotic obstruction.

\section{References}

1. Santos CLT, Sawada NO, Santos JLF. A avaliação da qualidade de vida relacionada à saúde de pacientes submetidos ao transplante de células-tronco hematopoéticas. Rev. Latino-Am. Enfermagem. nov-dez 2011;19(6):1322-8.

2. Silveira RCCP, Braga FTMM, Garbin LM, Galvão CM. $O$ uso do filme transparente de poliuretano no cateter venoso central de longa permanência. Rev. Latino-Am. Enfermagem. nov-dez 2010;18(6):1212-20.

3. Verso M, Agnelli $G$. Venous thromboembolism associated with long-term use of central venous catheters in câncer patients. J Clin Oncol. 2003 Oct $1 ; 21(19): 3665-75$.

4. Gallieni M, Pittiruti M, Biffi R. Vascular acess in oncology patients. CA Cancer J Clin. 2008 Nov-Dec;58(6):323-46. Epub 2008 Oct 29.

5. Solomon B, Moore J, Arthur C, Prince HM. Lack of efficacy of twice-weekly urokinase in the prevention of complications associated with Hickman catheters: a multicentre randomised comparison of urokinase versus heparin. Eur J Cancer. 2001 Dec;37(18):2379-84.

6. Kuter DJ. Thrombotic complications of central venous catheters in cancer patients. Oncologist. 2004;9(2):207-16.

7. Mendes KDS, Silveira RCCP, Galvão CM. Revisão integrativa: método de pesquisa para incorporação de evidências na saúde e na enfermagem. Texto Contexto Enferm. 2008;17(4):758-64.

8. Ursi ES, Galvão CM. Prevenção de lesões de pele no perioperatório: revisão integrativa da literatura. Rev. Latino-Am. Enfermagem. 2006;14(6):124-31.

9. Melnik BM, Fineout-Overholt E. Making the case for evidence-based practice. In: Melnik BM, Fineout-Overholt E. Evidence-based practice in nursing \& healthcare: a guide to Best practice. Philadelphia: Lippincot Williams \& Wilkins; 2011. p. 3-24.

10. Jadad AR, Moore RA, Carroll D, Jenkinson C, Reynolds DJ, Gavaghan DJ, et al. Assessing the quality of reports of randomized clinical trials: is blinding necessary? Control Clin Trials. 1996 Feb;17(1):1-12.

11. Lagro SW, Verdonck LF, Borel IHR, Dekker AW. No effect of nadroparin prophylaxis in the prevention of central venous catheter (CVC) associated thrombosis in boné marrow transplant recipients. Bone Marrow Transplant. 2000 Nov;26(10):1103-6.
12. Magagnoli M, Masci G, Castagna L, Pedicini V, Poretti $D$, Morenghi $E$, et al. Prophylaxis of central venous catheter-related thrombosis with minidose warfarin in patients treated with high-dose chemotherapy and peripheral-blood stem-cell transplantation: retrospective analysis of 228 cancer patients. Am J Hematol. 2006 Jan;81(1):1-4.

13. Horne MK, McCloskey DJ, Calis K, Wesley R, Childs R, Kasten-Sportes $C$. Use of heparin versus lepirudin flushes to prevent withdrawal occlusion of central venous Access devices. Pharmacotherapy. 2006 Sep;26(9):1262-7.

14. Drakos PE, Nagler A, Or R, Gillis S, Slavin S, Eldor A. Low-molecular-weight heparin for Hickman catheterinduced thrombosis in thrombocytopenic patients undergoing bone marrow transplantation. Cancer. 1992 Oct $1 ; 70(7): 1895-8$.

15. Haire WD, Lieberman RP, Edney J, Vaughan WP, Kessinger A, Armitage JO, et al. Hickman catheterinduced thoracic vein thrombosis. Frequency and long-term sequelae in patients receiving high-dose chemoterapy and marrow transplantation. Cancer. 1990 Sep 1;66(5):900-8.

16. Ulz L, Petersen FB, Ford R, Blakely W, Bennett C, Grimm $M$, et al. A prospective study of complications in Hickman right-atrial catheters in marrow transplant patients. J Parenter Enteral Nutr. 1990 JanFeb;14(1):27-30.

17. Karaby O, Yetkin U, Onol H. Upper extremity deep vein thrombosis: clinical and treatment characteristics. J Int Med Res. 2004 Jul-Aug;32(4):429-35.

18. Falanga A, Barbui T, Rickles FR. Hypercoagulability and tissue factor gene upregulation in hematologic malignances. Semin Thromb Hemost. 2008 Mar;34(2):204-10.

19. Stoffel N, Rysler C, Buser A, Gratwohl A, Tsakiris DA, Stern M. Leukocyte count and risk of thrombosis in patientes undergoing haematopoietic stem cell transplantation or intensive chemotherapy. Thromb Haemost. 2010 Jun;103(6):1228-32. Epub 2010 Mar 29. 20. Warkentin TE, Aird WC, Rand JH. Platelet-endothelial interactions: sepsis, HIT, and antiphospholipid syndrome. Hematology. [periódico na Internet]; [acesso 14 jul 2010]. 2003;(1):497-519. Disponível em: http:// asheducationbook.hematologylibrary.org/content/ vol2003/issue1/

21. Gettings EM, Brush KA, Van Cott EM, Hurford WE. Outcome of postoperative critically ill patients with heparin-induced thrombocytopenia: an observational retrospective case-control study. Crit Care. 2006;10(6): R161. 
22. Mitchell MD, Anderson BJ, Williams K, Umscheid CA. Heparin flushing and other interventions to maintain patency of central venous catheters: a systematic review. J Adv Nurs. 2009 Oct;65(10):2007-21.

23. Haire WD, Deitcher SR, Mullane KM, Jaff $M R$, Firszt CM, Schulz GA, et al. Recombinant urokinase for restoration of patency in occluded central venous access devices. A double-blind, placebo-controlled Trial. Thromb Haemost. 2004 Sep;92(3):575-82.

24. Winger L. Vascular access device thrombosis. Clin J Oncol Nurs. 2003 May-Jun;7(3):345-8.

25. Journeycake JM, Buchanan GR. Catheterrelated deep venous thrombosis and other catheter complications in children with cancer. J Clin Oncol. 2006 Oct $1 ; 24(28): 4575-80$.

26. Baskin JL, Pui $\mathrm{CH}$, Reiss $\mathrm{U}$, Wilimas JA, Metzger ML, Ribeiro RC, et al. Management of occlusion and thrombosis associated with long-term indwelling central venous catheters. Lancet. 2009 Jul 11;374(9684):159-69.

27. Deitcher SR, Fraschini G, Himmelfarb J, Schuman E, Smith TJ, Schulz GA, et al. Dose ranging trial with a recombinant urokinase (urokinase alfa) for occluded central venous catheters in oncology patientes. J Vasc Interv Radiol. 2004 Jun;15(6):575-80.

28. Kovacs MJ, Kahn SR, Rodger M, Anderson DR, Andreou R, Mangel JE, et al. A pilot study of central venous catheter survival in cancer patients using lowmolecular-weight heparin (dalteparin) and warfarin without catheter removal for the treatment of upper extremity deep vein thrombosis (The Catheter Sutdy). J Thromb Haemost. 2007 Aug;5(8):1650-3.

29. Couban S, Goobyear M, Burnell M, Dolan S, Wasi P, Barnes $D$, et al. Randomized placebo-controlled study of low-dose warfarin for the prevention of central venous catheter-associated thrombosis in patients with cancer. J Clin Oncol. 2005 Jun 20;23(18):4063-9.

30. Kokotis K. Cost containment and infusion services. J Infus Nurs. 2005 May-Jun;28(3 Suppl):S22-32;quiz S33-6.

31. Macklin D. Catheter management. Semin Oncol Nurs. 2010 May;26(2):113-20.

32. Hadaway LC. Reopen the pipeline for I.V. therapy. Nursing. 2005 Aug;35(8):54-61; quiz 61-3. 